\title{
Research Activities in the Spokane, Washington, Field Office
}

he U.S. Geological Survey
(USGS) Western Region
Mineral Resources Team is a
geographically diverse,
multidisciplinary group of geolo-
gists, geophysicists, geochemists,
and geographic information
systems (GIS) and remote-sensing
specialists working together and
with cooperators to assess the
mineral resources and mineral-
related environmental problems of
the Western United States. In
addition to the Spokane, Washing-
ton, Field Office, the team has
offices in Anchorage, Alaska,
Menlo Park, California, Reno,
Nevada, and Tucson, Arizona.
Additional information about these
offices and ongoing project work
can be obtained from the team's
Web site at http://minerals.usgs.
gov/west/.

Research conducted by the U.S. Geological Survey (USGS) at its Spokane Field Office has evolved to meet the changing needs of our Nation. The Spokane Field Office was established in 1942 to facilitate the Strategic Minerals Program during World War II. Work conducted under this program established the existence of a major zinclead ore body at Metaline, Washington, and the presence of tungsten at the Yellow Pine antimony-gold mine at Stibnite, Idaho. Both deposits were mined during the war. Field investigations by the USGS under the Strategic Minerals Program also led to discovery of significant reserves of cobalt in the Blackbird mining district of Lemhi County, Idaho.

After the war, several major research projects were started in the Pacific Northwest and headquartered in Spokane. These projects included the Western Phosphate Project under the direction of Vince McKelvey, an intensive study of the Coeur d'Alene district under the direction of S. Warren Hobbs, and a major study of the Boulder Batholith, Montana, and its relation

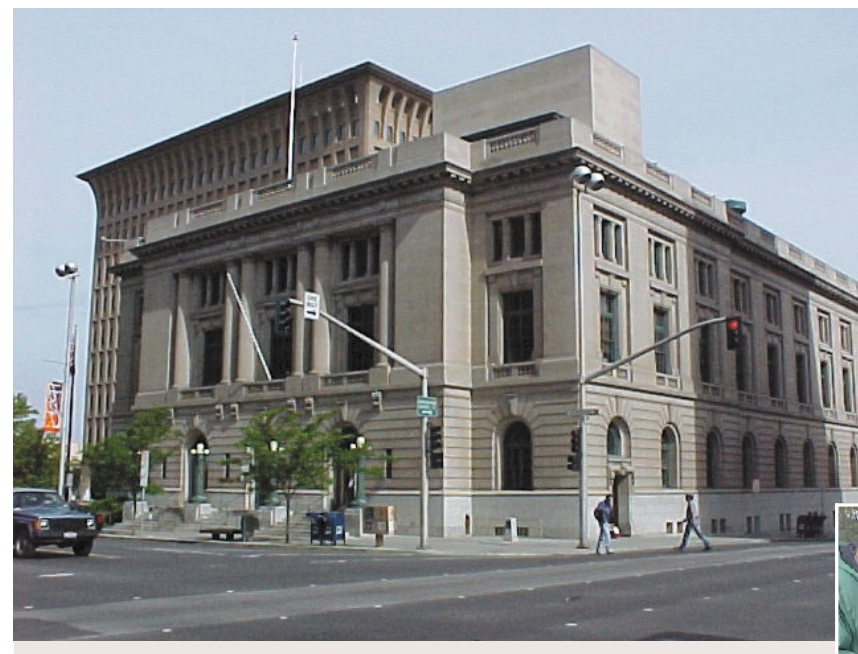

Research conducted by the U.S. Geological Survey at its Spokane Field Office (in the building pictured above) has evolved to meet the changing needs of our Nation. The Spokane Field Office was established in 1942 to facilitate the Strategic Minerals Program during World War II. Work conducted under this program established the existence of a major zinc-lead ore body at Metaline, Washington, and the presence of tungsten at the Yellow Pine antimony-gold mine at Stibnite, Idaho. Both deposits were mined during the war.

U.S. Geological Survey scientists (photo below) are tracking the pathways of metals from mine-tailingsimpacted flood plains to the Coeur d'Alene River to provide a scientific basis for remediation strategies. The research goals are to understand how these ore deposits formed, how much ore and mining waste is present, and how mining wastes have affected the environment.

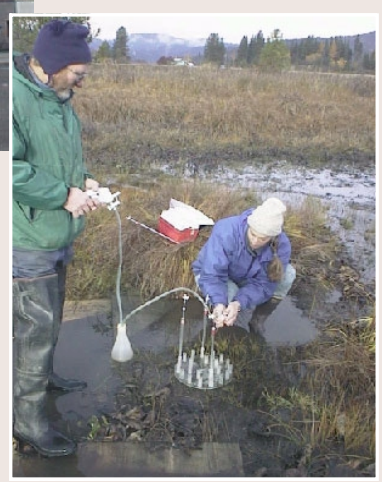

to metalliferous-mineral deposits under the direction of Monte R. Klepper. Although these studies focused on the identification of resources that would prove to be important to the Nation, their research findings provide the foundation for two current research projects, which are considering both the resource and environmental aspects of these mineralized rocks.

In 1951, the Korean War created another change in USGS work done from the Spokane Field Office. With little mineral exploration being done by mining companies during the Depression of the 1930's and during World War II, most company activity was directed at mineral production. At the onset of the Korean War, the Nation's mineral-resource base was at a low ebb. To help correct that situation, the Federal Government established the Defense Minerals Exploration Administration (DMEA) to help mining companies in the exploration for strategic and critical minerals. The USGS provided geological expertise to the DMEA, and A.E. Weissenborn, head of the Spokane Field Office, was designated by DMEA as Executive Officer in charge of fieldwork done for DMEA by the USGS and the U.S. Bureau of Mines in the States of Montana, Idaho, Oregon, and Washington. The Northwest became the most active mineral-exploration region in the United States, and DMEA work resulted in several major mineral discoveries. The efforts of the USGS Outreach and Technology Exchange project are ensuring that the results of this program will be available to researchers and the public.

Legislation passed in the 1970's required that management plans be developed for lands administered by the U.S. Forest Service (USFS) and the Bureau of Land Management (BLM). Beginning in the 1980's, USGS staff began to conduct mineral-resource assessments for the USFS and BLM in Washington, Oregon, Idaho, and western Montana. The initial work focused on estimating mineral-resource potential for proposed Wilderness Areas; later mineral-resource assessments were conducted for National Forests and BLM Resource Areas to provide information needed to develop management plans. The current Headwaters project reflects the evolution of these studies to assess potential for development and to conduct work on the relation of geology to ecosystem function. 


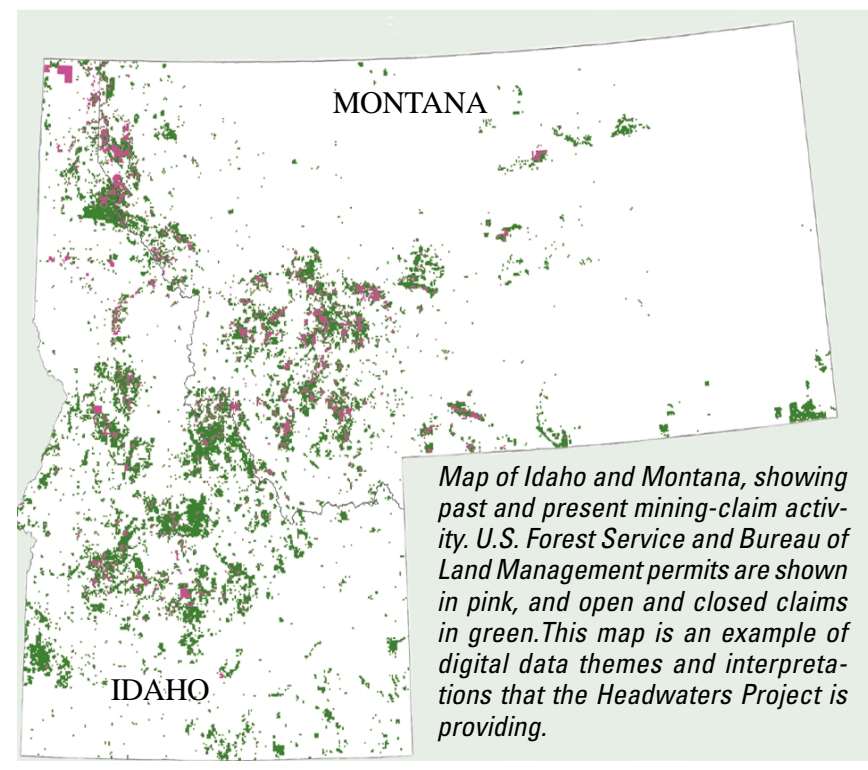

\section{Current research activities}

\section{Geologic and geoenvironmental studies of the Western Phosphate Field}

Large, high-grade phosphate deposits of the Western Phosphate Field, a 135,000-squaremile area of the northern Rocky Mountains, constitute an important economic resource that has been mined for nearly 100 years. Phosphorus, the sought-after component of phosphate ore, is an essential element for plant and animal nutrition. The principal use for phosphorus is as a fertilizer; other chemical applications include use in water softeners, detergents, and food additives. The development of phosphate resources as a leasable commodity provides income to the Government in the form of royalties. Federal land-management agencies, such as the BLM and the USFS, must ensure that lease royalties reflect the fair market value of the resource and that mining, waste disposal, and processing are accomplished in an environmentally sound manner. This project characterizes phosphate resources in the Western Phosphate Field, the residence time and behavior of potentially harmful trace elements, such as selenium, and the impact of the occurrences and development of phosphate deposits on the environment. For more information about this project, contact Phil Moyle, (509) 368-3109 / pmoyle @usgs.gov.

\section{Coeur d'Alene life-cycle models}

The Coeur d'Alene mining district in Idaho is one of the world's largest producers of silver and one of our Nation's major historical producers of lead and zinc. Although environmentally sound mining practices are conducted within the district today, historical oreprocessing methods and episodic floods have dispersed metal-enriched sediment at least 150 miles downstream from the mining district. Residents in and near the district, along with local, State, and Federal agencies, are working to reduce human and wildlife health effects from the contaminated sediment and reduced water quality. Research goals are to understand how these ore deposits formed, how much ore and mining waste is present, and how mining wastes have affected the environment. The major product of this work will be an integrated, comprehensive life-cycle model for Coeur d'Alene-type deposits, presented in a series of digital maps, reports, journal articles, meeting presentations, and Fact Sheets. For more information about this project, contact Steve Box, (509) 368-3106 / sbox@usgs .gov or Laurie Balistrieri, (206) 543-8966 / balistri@usgs.gov.

\section{Headwaters Province, Idaho and Montana}

This project is providing regionally consistent digital data themes and interpretations and the results of process-based topical studies to the BLM and the USFS in Idaho and Montana. These agencies intend to include this information in GIS-based science integration and planning. The results can be applied to forest-plan revisions, quick-response assessments (such as those conducted to address issues that arise from listing of threatened and endangered species), characterization studies that are part of ongoing watershed-restoration efforts, and research on the relation of geology to ecosystem function.

The major goals of the project are to: (1) provide digital geoscience databases for the province; (2) advance the understanding of mineral resources within a geologic, economic, and environmental context; (3) establish a geologic context for ecosystem structure and function; and (4) forecast near-future mineral exploration and development activities, using reproducible, GIS-based methods. For more information about this project, contact Mike Zientek, (509) 368-3105/mzientek @usgs.gov or Karen Lund (303) 236-5600 / klund@usgs.gov.

\section{Outreach and Technology Exchange}

This project helps provide users with easily accessible, accurate, up-to-date mineral-resource information that is available from the USGS. In Spokane, the Outreach and Technology Exchange project has archived files from Defense Minerals Administration, Defense Minerals Exploration Administration, and Office of Minerals Exploration programs.

From the early 1950's through 1974, these Federally funded programs provided financial assistance, on a joint-participation basis, to support exploration for strategically important commodities. Nearly 5,000 dockets or files, which were prepared as a result of these partnerships, have been indexed and archived for easier access. Materials in these dockets may contain correspondence, reports, maps, contracts, and sample analyses. The archives are open to the public by appointment, and customers are asked to make an initial data inquiry to define their request. For more information about this project or the archives housed at the Spokane Field Office, contact Dave Frank, (509) 368-3107 / dfrank@usgs.gov.

Meeting the challenge of balancing America's needs for both nonrenewable resources and a clean and healthy environment requires accurate and unbiased scientific data. The ongoing work of scientists at the Spokane Field Office helps to provide information crucial to the creation of sound policies that will ensure future supplies of mineral resources while protecting the health of our Nation's citizens.

Dave Frank, Philip Moyle, Steve Box, and Mike Zientek

Graphic design by Judy Weathers

For more information contact:

U.S. Geological Survey

904 W. Riverside Avenue, Room 202

Spokane, WA 99201-1087

Telephone: (509) 368-3101

Fax: (509) 368-3199

http://minerals.usgs.gov/west/ 